\title{
Comunicação
}

[Communication]

\section{Valor nutricional de híbridos de sorgo com capim-sudão em comparação ao de outros volumosos utilizados no período de baixa disponibilidade das pastagens}

\author{
[Nutritional value of sorghum-sudangrass hybrids compared to other roughage sources used \\ in the period of low availability of pastures] \\ T.R. Tomich ${ }^{1 *}$, R.G.P. Tomich ${ }^{2}$, L.C. Gonçalves ${ }^{3}$, I. Borges ${ }^{3}$, J.A.S. Rodrigues ${ }^{4}$ \\ ${ }^{1}$ Embrapa Pantanal \\ Caixa Postal 109 \\ 79320-900 - Corumbá, MS \\ ${ }^{2}$ Instituo de Ciências Biológicas da UFMG - Belo Horizonte, MG \\ ${ }^{3}$ Escola de Veterinária da UFMG - Belo Horizonte, MG \\ ${ }^{4}$ Embrapa Milho e Sorgo - Sete Lagoas, MG
}

Entre as principais estratégias utilizadas para manter o adequado suprimento de volumosos para os rebanhos durante o período anual de seca, quando ocorre escassez das pastagens, destacam-se o uso de pastagens diferidas, vedadas no final da estação de crescimento; as reservas de forragem manejadas em regime de corte, como as capineiras, as lavouras de canade-açúcar e o emprego de volumosos conservados, pela fenação ou pela ensilagem. Segundo Rodrigues (2000), os híbridos de sorgo granífero (Sorghum bicolor, cv. bicolor) com capim-sudão ( $S$. bicolor, cv. sudanense), chamados de sorgos de corte e pastejo, vêm-se destacando como mais um recurso disponível para manter a estabilidade da produção de forragem ao longo do ano, por serem plantas adaptadas à baixa disponibilidade de água, apresentarem elevado rendimento forrageiro, alta capacidade de germinação, grande velocidade de crescimento e boa habilidade para perfilhamento e rebrota. Este trabalho objetivou comparar o valor nutritivo de híbridos de sorgo com capimsudão manejados em regime de corte ao de outros recursos forrageiros comumente utilizados na estação seca.
Os volumosos estudados foram: a planta inteira de híbridos de sorgo com capim-sudão, cultivares AG2501C e BRS800, com 30 dias de rebrota; o terço superior de plantas colhidos em pastagens diferidas de braquiarão (Brachiaria brizantha) e de decumbens (Brachiaria decumbens), com 90 dias de veda; planta inteira de cana-de-açúcar (Saccharum officinarum) e de capim-elefante (Pennisetum purpureum) colhidas cerca de 12 meses após o plantio e 30 dias de rebrota, respectivamente; os fenos de gramíneas do gênero Cynodon, coast-cross e tifton 85, adquiridos no comércio de produtos agropecuários e as silagens de milho (Zea mays) e de sorgo granífero produzidas com a planta inteira, nos respectivos estádios de desenvolvimento indicados para a ensilagem.

As amostras dos volumosos, após a pré-secagem, foram analisadas quanto aos conteúdos de matéria seca $(\mathrm{MS})$ a $105^{\circ} \mathrm{C}$, de proteína bruta (PB) pelo método de combustão, fibra em detergente neutro (FDN), fibra em detergente ácido (FDA) e lignina pelo método seqüencial (Van Soest et al., 1991). Empregando-se a metodologia proposta por Tilley e Terry (1963), os volumosos foram comparados em um ensaio de digestibilidade in vitro da matéria seca 
(DIVMS), utilizando-se inóculos ruminais distintos, coletados em três semanas consecutivas de um bovino mantido em dieta composta por volumoso à vontade e $2 \mathrm{~kg} / \mathrm{dia}$ de concentrado comercial com $22 \%$ de PB. O delineamento experimental foi inteiramente ao acaso, com 10 tratamentos (volumosos) e três repetições (inóculos de rúmen) e as médias foram comparadas pelo teste Student-Newman-Keuls com 5\% de probabilidade. $\mathrm{Na}$ análise de variância, usou-se o modelo estatístico: $\mathrm{Y}_{\mathrm{ij}}=\mu+$ $\mathrm{V}_{\mathrm{j}}+\varepsilon_{\mathrm{ij}}$, em que: $\mathrm{Y}_{\mathrm{ij}}=$ digestibilidade do volumoso j utilizando-se o inóculo $\mathrm{i} ; \mu=$ média geral; $\mathrm{V}_{\mathrm{j}}=$ efeito do volumoso $\mathrm{j},(\mathrm{j}=1,2,3,4,5$, $6,7,8,9,10)$ e $\varepsilon_{\mathrm{ij}}=$ erro experimental. Para a análise dos dados, foi utilizado o programa SAEG (Ribeiro Júnior, 2001).

Procurou-se na determinação dos volumosos, a serem comparados aos híbridos de sorgo com capim-sudão, abranger aqueles que fossem representativos das principais estratégias utilizadas no país como recursos forrageiros empregados no período de escassez das pastagens. Ressalta-se que o uso do terço superior das plantas nas pastagens diferidas visou coletar a porção que apresenta a maior probabilidade de ser consumida pelos animais em pastejo. Para os outros volumosos, foram utilizadas plantas inteiras, pois o emprego desses envolve os processos de corte e fornecimento no cocho, o que dificulta a seleção da forragem consumida.

A composição bromatológica e as médias de DIVMS dos volumosos são apresentados na Tab. 1. Os conteúdos de MS variaram de $16,6 \%$ a $90,4 \%$. Essa grande variação foi determinada pelos tipos de alimentos avaliados, forragens verdes, silagens e fenos. Os dois híbridos de sorgo de corte se destacaram dos demais volumosos devido ao elevado teor protéico. A média de 14,5\% de $\mathrm{PB}$ apresentada pelos híbridos AG2501C e BRS800 foi, no mínimo, cerca de $75 \%$ superior aos conteúdos de proteína apresentados pelos outros volumosos, que variaram de $1,3 \%$ a 8,2\%. De acordo com Preston (1982), ruminantes alimentados com dietas baixas em proteína apresentam consumo reduzido e desempenho em nível de mantença, ou baixa produtividade, mesmo quando suplementados com nitrogênio não protéico. Dessa forma, o conteúdo de PB apresentado pelos híbridos de sorgo de corte neste estudo indica que a utilização desses cultivares pode apresentar vantagem em relação aos demais volumosos avaliados, porque o seu uso pode diminuir a necessidade de suplementação protéica na forma de concentrados e, conseqüentemente, reduzir os custos com a alimentação dos rebanhos.

Tabela 1. Valores de matéria seca (MS), proteína bruta (PB), fibra em detergente neutro (FDN), fibra em detergente ácido (FDA), lignina e médias de digestibilidade in vitro da matéria seca (DIVMS) dos volumosos

\begin{tabular}{llcccccc}
\hline \multirow{2}{*}{ Volumoso } & \multirow{2}{*}{ MS (\%) } & PB & FDN & FDA & Lignina & DIVMS \\
\cline { 5 - 8 } Sorgo de & AG2501C & 16,7 & 14,6 & 65,1 & 35,8 & 4,1 & $63,9 \mathrm{~A}$ \\
corte & BRS800 & 16,6 & 14,4 & 64,4 & 35,3 & 4,1 & $65,6 \mathrm{~A}$ \\
Pastagem & Braquiarão & 25,7 & 4,9 & 74,6 & 38,5 & 3,1 & $58,3 \mathrm{~B}$ \\
diferida & Decumbens & 28,1 & 3,6 & 78,8 & 45,1 & 4,2 & $54,1 \mathrm{C}$ \\
Forrageira & Cana-de-açúcar & 27,5 & 1,3 & 49,8 & 30,8 & 4,9 & $61,5 \mathrm{AB}$ \\
de corte & Capim-elefante & 17,4 & 8,2 & 70,8 & 37,6 & 3,4 & $65,5 \mathrm{~A}$ \\
\multirow{2}{*}{ Feno } & Coast-cross & 90,4 & 6,0 & 75,4 & 38,3 & 4,8 & $54,5 \mathrm{C}$ \\
& Tifton 85 & 88,1 & 7,3 & 81,8 & 39,4 & 4,7 & $52,7 \mathrm{C}$ \\
\multirow{2}{*}{ Silagem } & Milho & 27,3 & 7,2 & 51,5 & 32,2 & 4,0 & $61,8 \mathrm{AB}$ \\
& Sorgo & 31,7 & 6,8 & 59,1 & 35,9 & 4,9 & $53,0 \mathrm{C}$ \\
\hline
\end{tabular}

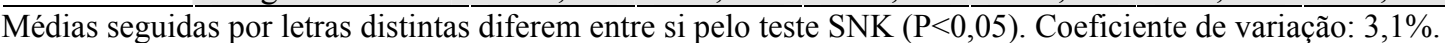

Em relação aos componentes da parede celular, os híbridos de sorgo de corte apresentaram conteúdos intermediários de FDN, FDA e lignina, quando comparados aos outros volumosos. Sob a perspectiva do valor nutritivo, conforme Van Soest (1994), embora as características intrínsecas da parede celular, representadas por aspectos físicos e pela relação estabelecida entre as frações constituintes, sejam mais importantes na regulação da digestibilidade 
do que as proporções desses componentes, o aumento dessas frações também está relacionado às reduções na digestibilidade e no consumo. $\mathrm{O}$ conteúdo de FDN relaciona-se principalmente à redução no consumo, enquanto as frações de FDA e lignina estão mais associadas à redução na digestibilidade. Estudo realizado por Ademosum et al. (1968) mostrou que o conteúdo de fibra da forragem produzida por híbridos de sorgo com capim-sudão é significativamente afetado pelo estádio de desenvolvimento das plantas. Assim, visando conciliar o rendimento forrageiro ao valor nutritivo, têm-se recomendado a utilização desses híbridos em torno de 30 a 45 dias após o plantio ou de rebrota.

No ensaio de digestibilidade, os híbridos de sorgo de corte, com valores de 63,9\% (AG2501C) e 65,9\% (BRS800), o capimelefante, com $65,5 \%$, a silagem de milho, com $61,8 \%$ e a cana-de-açúcar, com $61,5 \%$, apresentaram os mais altos $(\mathrm{P}<0,05)$ resultados de DIVMS, que equivaleram entre si $(\mathrm{P}>0,05)$. A média de $58,3 \%$ de DIVMS obtida para a forragem colhida na pastagem diferida de braquiarão foi semelhante $(\mathrm{P}>0,05)$ às médias encontradas para a silagem de milho e para a cana-de-açúcar, mas inferiores $(\mathrm{P}<0,05)$ às médias dos híbridos de sorgo com capim-sudão e do capim-elefante. A forragem coletada na pastagem diferida de decumbens $(54,1 \%)$, os fenos de coast-cross $(54,5 \%)$ e de tifton 85 $(52,7 \%)$ e a silagem de sorgo $(53,0 \%)$ apresentaram as mais baixas $(\mathrm{P}<0,05)$ médias de DIVMS. Conforme Van Soest (1994), os alimentos não são iguais em sua capacidade de dar suporte às funções de mantença, crescimento ou produção. Eles suprem energia e nutrientes essenciais, na forma de proteína, vitaminas e minerais. Proteína e energia são, geralmente, os principais fatores limitantes para os ruminantes e têm recebido mais atenção, já que as possíveis deficiências em minerais e vitaminas são supridas via suplementação. Uma vez que a fração de parede celular (FDN) constitui, em regra, o principal componente da MS dos volumosos, a determinação da digestibilidade da MS desse tipo de alimento reflete, em grande parte, a digestibilidade da FDN. A digestão microbiana dos carboidratos contidos na FDN supre energia para o ruminante, pela produção de ácidos graxos voláteis. Por sua vez, desde que o conteúdo de nitrogênio não se encontre em níveis limitantes, a digestão de carboidratos no rúmen também supre proteína para o ruminante, por propiciar o desenvolvimento microbiano. Portanto, o coeficiente de digestibilidade da MS do volumoso pode, em muitas situações, ser utilizado para estimar o seu valor nutritivo, não somente sob o aspecto energético. Desta forma, os resultados de digestibilidade obtidos no presente estudo também destacaram o elevado valor nutritivo da forragem dos híbridos de sorgo com capim-sudão e os credenciam para a produção de volumoso no período de escassez das pastagens.

Deve-se considerar que a produção de silagem e de feno exige, normalmente, melhor capacidade técnica do produtor e maior número de implementos em relação ao fornecimento de forragem de corte. Também deve ser levado em consideração, que ao final do período seco, a pastagem diferida, geralmente, se apresenta com baixo valor nutritivo, devido à reduzida taxa de crescimento nesse período. Além disso, o manejo das capineiras do capim-elefante para se obter volumoso de boa qualidade durante a seca é difícil pois, segundo Botrel e Alvim (1992), os cultivares disponíveis produzem apenas $10 \%$ $15 \%$ do rendimento anual de forragem durante esse período, sendo freqüentemente observado o fornecimento de capim-elefante em estádio avançado de desenvolvimento, com baixo valor nutritivo. Ainda, conforme Peixoto (1986), a cana-de-açúcar apresenta baixa degradação ruminal da parede celular, o que pode restringir a sua aplicação para categorias mais exigentes, ou para animais com alto potencial para produção.

Portanto, este estudo mostrou que os híbridos de sorgo de corte avaliados apresentam composição bromatológica e coeficientes de DIVMS semelhantes entre si e se destacam em relação aos outros volumosos avaliados quanto ao teor protéico superior e à alta digestibilidade. Nas mesmas condições de plantio e utilização deste estudo, esses híbridos apresentam-se como opção de volumoso de elevado valor nutritivo para o período de escassez das pastagens.

Palavras-chave: composição bromatológica, digestibilidade, ruminante, sorgo-capim-sudão 


\begin{abstract}
The objective of this study was to compare the nutritional value of sorghum-sudangrass hybrids to roughages collected in differed pastures, reserves of forage for using in cutting regime and conserved forage as hays or silages. The sorghum-sudangrass hybrids AG2501C and BRS800 showed similar bromatological composition and in vitro dry matter digestibility (IVDMD). Compared to other roughages, theses hybrids presented a higher protein level and intermediary values of cell wall contents. The coefficients of IVDMD observed for sorghum-sudangrass hybrids were not statistically different to the results of corn silage, elephantgrass and sugarcane managed in cutting regime. However, IVDMD of those hybrids was significantly higher than of coast-cross and tifton 85 hays, sorghum silage and differed pastures of Brachiaria brizantha and signal grass. The results indicated that sorghum-sudangrass hybrids may be used as roughage of high nutritional value during the drought.
\end{abstract}

Keywords: bromatological composition, digestibility, ruminant, sorghum-sudangrass hybrid

\section{REFERÊNCIAS BIBLIOGRÁFICAS}

ADEMOSUM, A.A., BAUMGARDT, B.R., SCHOLL, J.M. Evaluation of a sorghumsudangrass hybrid at varying stages of maturity on the basis of intake, digestibility and chemical composition. J. Anim. Sci., v.27, p.818-823, 1968.

BOTREL, M.A., ALVIM, M.J. Avaliações agronômicas de cultivares de capim-elefante em duas regiões fisiográficas do Estado de Minas Gerais. Pesq. Agropec. Bras., v.27, p.835-839, 1992.

PEIXOTO, A.M. A cana de açúcar como recurso forrageiro. In: CONGRESSO BRASILEIRO DE PASTAGENS, 1986, Piracicaba. Anais... Piracicaba: FEALQ, 1986. p.17-47.

PRESTON, T.R. Nutritional limitations associated with the feeding of tropical forages. $J$. Anim. Sci., v.54, p.877-884, 1982.
RIBEIRO JÚNIOR, J.I. Análises estatísticas no SAEG. Viçosa: UFV, 2001. 301p.

RODRIGUES, J.A.S. Utilização de forragem fresca de sorgo (Sorghum bicolor x Sorghum sudanense) sob condições de corte e pastejo. In: SIMPÓSIO DE FORRAGICULTURA E PASTAGENS: TEMAS EM EVIDÊNCIA, 2000, Lavras. Anais... Lavras: UFLA, 2000. p.179-201.

TILLEY, J.M.A., TERRY, R.A. A two-stage technique for the "in vitro" digestion of forage crops. J. Brit. Grassl. Soc., v.18, p.104-111, 1963.

VAN SOEST, P.J. Nutritional ecology of the ruminant. 2.ed. Ithaca: Cornell University. 1994. 476p.

VAN SOEST, P.J., ROBERTSON, J.B., LEWIS, B.A. Methods for dietary fiber, neutral detergent, and nonstarch polysaccharides in relation to animal nutrition. J. Dairy Sci., v.74, p.35833597, 1991. 